
\title{
$\begin{array}{ll}\text { Research Square } & \begin{array}{l}\text { Preprints are preliminary reports that have not undergone peer review. } \\ \text { They should not be considered conclusive, used to inform clinical practice, } \\ \text { or referenced by the media as validated information. }\end{array}\end{array}$
}

\section{A Liquid Chromatographic Method for Determination of Acetamiprid and Buprofezin Residues and Their Dissipation Kinetics in Paddy Matrices and Soil}

Sujan Majumder

IIVR: Indian Institute of Vegetable Research

Somnath Mandal

North Bengal Agricultural University: Uttar Banga Krishi Viswavidyalaya

Biswajit Majumder

North Bengal Agricultural University: Uttar Banga Krishi Viswavidyalaya

Anindita Paul

CTRI Rajahmundry: Central Tobacco Research Institute

Tarun Paul

North Bengal Agricultural University: Uttar Banga Krishi Viswavidyalaya

Nandita Sahana

North Bengal Agricultural University: Uttar Banga Krishi Viswavidyalaya

PRITHUSAYAK MONDAL ( $\nabla$ prithusayak@gmail.com)

Uttar Banga Krishi Viswavidyalaya https://orcid.org/0000-0002-3289-9853

\section{Research Article}

Keywords: Acetamiprid, Buprofezin, Insecticide residues, Method validation, Persistence, Paddy, Soil, Consumer safety

Posted Date: June 28th, 2021

DOI: https://doi.org/10.21203/rs.3.rs-225672/v2

License: (c) (i) This work is licensed under a Creative Commons Attribution 4.0 International License. Read Full License

Version of Record: A version of this preprint was published at Environmental Science and Pollution Research on August 5th, 2021. See the published version at https://doi.org/10.1007/s11356-021-15784-4. 


\section{Abstract}

The present study was conducted to investigate the residue status of two insecticides (acetamiprid and buprofezin) and their dissipation kinetics in three matrices viz. paddy grain, straw and soil. The extraction protocol for residues of these two insecticides was executed using acetonitrile solvent. The analytical method was validated, which showed good linearity with the limit of quantification (LOQ) value of 0.01 and $0.02 \mathrm{mg} \mathrm{kg}^{-1}$ for acetamiprid and buprofezin respectively. The recovery range was $79.67-98.33 \%$ concerning all the matrices in both the insecticides. Acetamiprid (20\% SP) and Buprofezin (25\% SC) were applied separately in the paddy field in two doses: single dose (recommended dose) and double dose along with untreated control throughout the experiment. Residue analysis of these two insecticides in paddy (grain and straw) and soil was accomplished employing high-pressure liquid chromatography (HPLC) with a UV detector. The dissipation data showed that acetamiprid exhibited higher dissipation in comparison with buprofezin. However, their persistence was found slightly higher in soil. The dissipation dynamics in the rice and soil were discussed with biological half-lives of both the insecticides. Consumer risk assessment study was also made considering its fate to the consumers.

\section{Introduction}

Rice (Oryza sativa) is one of the prime staples for people in low- and lower-middle-income countries that feeds over half of the world's population (Sen et al. 2020). It, being the most consumed cereal in Asia, has profuse economic importance in national and international markets (Bajaj and Mohanty 2005; Burlando and Cornara 2014). India occupies the largest area (43.5 Mha) under rice cultivation and ranks second in production (163.52 MT) in the world (IRRI 2020). The fruitful cultivation of paddy is often drastically thwarted due to preponderance of insect pests (Thongphak et al. 2012). There are nearly twenty insects considered to be rice pests of economic importance including stem borers, gall midge, defoliators and vectors like leafhoppers and planthoppers that hamper rice ecosystem balance causing direct ravages and disease transmission (Ane and Hussain 2016). To combat these pests, synthetic insecticides are generally applied as frontline defence strategies. Acetamiprid (IUPAC name: N-[(6-chloro-3-pyridyl)methyl]-N'-cyano-N-methyl-acetamidine) is a systemic, odourless, neonicotinoid insecticide, developed and marketed by Nippon Soda Co. Ltd., Japan, under the trade name MOSPILAN for the control of sucking insects, generally recommended by Central Insecticide Board (CIB) and Registration Committee (RC) for solo use in rice, cotton, chilli, okra and cabbage in India (DPPQS 2020). This insecticide is a nerve poison that acts as a nicotinic acetylcholine receptors (nAChRs) agonist, which makes it extremely effective in managing insect pests like aphids, jassids, whiteflies, leafhoppers, thrips, bugs and borers (Tomizawa and Casida 2005). Another novel insecticide, Buprofezin (IUPAC name: (2Z)-3-Isopropyl-2-[(2-methyl-2-propanyl)imino]-5-phenyl-1,3,5-thiadiazinan-4-one), developed and marketed by Nihon Nohyaku Co. Ltd., Japan, under trade name APPLAUD, which is an insect growth regulator which is recommended for solo use in rice, cotton, chilli, okra, mango and grape in India (DPPQS 2020). This thiadiazine-like compound acts on the nymph stages of planthoppers, leafhoppers, mealybugs, scales, and whiteflies, and drastically hampers chitin synthesis (Ishaaya et al. 2007; De Cock and Degheele 1998).

Injudicious application of these insecticides may pose a serious threat to human beings because of the residues present there. Various residue analysis methods for acetamiprid and buprofezin were followed using standardized chromatographic protocols (GC/ GC-MS/ LC/ LC-MS) (Wartono et al. 2018; Wu et al. 2012; Sanyal et al. 2008; Lee and Jang 2010). Analysis of buprofezin residues was done earlier in soil (Yu et al. 2016) and various crops like vegetables (Valverde-Garcia et al. 1993), rice (Melo et al. 2020), tea (Chen et al. 2017), grapes (Oulkar et al. 2009) etc. A similar type of analysis was carried out for acetamiprid in crops like paddy (Saha et al. 2017), fruits and vegetables (Obana et al. 2002) and soil (Gupta and Gajbhiye 2007). However, there exists hardly any study of persistence-dissipation of these two insecticides under tropical climate. As both of these insecticides are well utilized in rice, there should be a study of the residue dynamics of these insecticides in different matrices.

The current research paper, therefore, conveys the dissipation dynamics of acetamiprid and buprofezin in paddy (grain and straw) and soil for different doses of applications. In view of the above, the authors have validated the method for residue analysis of these two insecticides in the matter of the precision in results using HPLC, and tried to comprehend their actual residue status in various matrices and concluded with consumer safety issues.

\section{Materials And Methods Chemicals and reagents}

Acetonitrile (HPLC grade) and water (HPLC grade) were purchased from Sigma-Aldrich, India. Analytical Reagent (AR) grade chemicals - Anhydrous sodium sulfate $\left(\mathrm{Na}_{2} \mathrm{SO}_{4}\right)$, Sodium chloride $(\mathrm{NaCl})$, Sodium citrate dibasic sesquihydrate $\left(\mathrm{C}_{6} \mathrm{H}_{6} \mathrm{Na}_{2} \mathrm{O}_{7} \cdot 1.5 \mathrm{H}_{2} \mathrm{O}\right)$, Sodium citrate tribasic hydrate $\left(\mathrm{C}_{6} \mathrm{H}_{5} \mathrm{Na}_{3} \mathrm{O}_{7} \cdot \mathrm{xH}_{2} \mathrm{O}\right)$ were acquired from Thomas Baker, Mumbai, India. Ultrapure water (HPLC grade) was taken from Sartorius water purification system (Sartorius AG, Goettingen, Germany). Primary secondary amine (PSA, $40 \mu \mathrm{m}$ ) was procured from Agilent Technologies, Bangalore, India.

\section{Apparatus}

Mixer Grinder (Bajaj India Pvt. Ltd., Mumbai, India), homogenizer (Heidolph 900, Germany), Mettler Toledo electronic balance (with an accuracy of 0.01 mg), vortex mixer (Geni 2T, Imperials Biomedicals, Mumbai, India), centrifuge (Kubota, Germany), microcentrifuge (Microfuge Pico, Kendro, D-37520, Osterode, Germany), Mechanical shaker and ultrasonic bath (Oscar electronics, Mumbai, India), P.P Centrifuge tubes of 50 ml capacity, Click lock centrifuge tubes of 2 $\mathrm{ml}$ capacity, Volumetric flasks of $10 \mathrm{ml}$ and $50 \mathrm{ml}$ capacity (Grade A), Volumetric pipettes of $1 \mathrm{ml}, 5 \mathrm{ml}$ and $10 \mathrm{ml}$ capacity (Grade A), Micropipette (100-1000 $\mu 1)$, and Micro tips HPLC auto-sampler vial $(2 \mathrm{ml})$ were used.

\section{Reference standard}


The certified reference materials (CRMs) of both acetamiprid (having $99.9 \%$ purity) and buprofezin (having $99.1 \%$ purity) were obtained from Krishi Rasayan Exports Pvt. Ltd., India. Standard stock solutions (stored in refrigerator at $-20^{\circ} \mathrm{C}$ ) were prepared by dissolving $10( \pm 0.1) \mathrm{mg}$ of $\mathrm{CRMs}$ in $10 \mathrm{ml}$ of methanol resulting in a final concentration of $1000 \mu \mathrm{g} \mathrm{ml}^{-1}$. A working standard mixture of $10 \mu \mathrm{g} \mathrm{ml}^{-1}$ was prepared in methanol by duly mixing the individual standard stock solutions followed by subsequent dilution, from which the calibration standard solutions of $0.01,0.025,0.05,0.1,0.25$ and $0.5 \mu \mathrm{g} \mathrm{ml} \mathrm{I}^{-1}$ were made. The matrix-matched standards of the same concentrations were made using the control rice extracts acquired from the sample preparation procedure.

\section{Field experiment}

The field (longitude: $89.386^{\circ} \mathrm{E}$, latitude: $26.402^{\circ} \mathrm{N}$ ) trial was conducted on Swarna variety of kharif paddy at Uttar Banga Krishi Viswavidyalaya, Pundibari, Cooch Behar under Terai agro-climatic zone of West Bengal, during July to November in 2018 following Randomized Block Design (RBD). The meteorological conditions and soil properties during the study period are shown in Table 1.

Table 1

Meteorological and soil physico-chemical parameters of the site of experiment

\begin{tabular}{|c|c|c|c|}
\hline $\begin{array}{l}\text { Sl. } \\
\text { No. }\end{array}$ & Parameters & Result & Methods of determination \\
\hline \multicolumn{4}{|c|}{ Meteorological conditions } \\
\hline 1 & Av. temperature $\left.(\max )^{\circ} \mathrm{C}\right)$ & 36.25 & Modified Blaney-Criddle method (Zhan and Lin 2009) \\
\hline 2 & Av. temperature $\left.(\min ){ }^{\circ} \mathrm{C}\right)$ & 18.58 & Modified Blaney-Criddle method (Zhan and Lin 2009) \\
\hline 3 & Av. rainfall (max) (mm) & 9.79 & Rain gauge method (WMO 2009) \\
\hline 4 & Av. rainfall (min) (mm) & 1.75 & Rain gauge method (WMO 2009) \\
\hline 5 & $\begin{array}{l}\text { Av. relative humidity (max) } \\
(\%)\end{array}$ & 93.27 & Psychrometer method (Gorse et al. 2012) \\
\hline 6 & $\begin{array}{l}\text { Av. relative humidity }(\mathrm{min}) \\
(\%)\end{array}$ & 43.53 & Psychrometer method (Gorse et al. 2012) \\
\hline \multicolumn{4}{|c|}{ Soil properties } \\
\hline 1 & Sand (\%) & 16.77 & Hydrometer method (Bouyoucos 1962) \\
\hline 2 & Silt (\%) & 44.12 & Hydrometer method (Bouyoucos 1962) \\
\hline 3 & Clay (\%) & 39.25 & Hydrometer method (Bouyoucos 1962) \\
\hline 4 & $\mathrm{pH}$ (soil: water ratio $1: 2.5$ ) & 5.57 & Digital pH meter (consisting of glass and calomel electrodes) (Jackson 1973) \\
\hline 5 & $\mathrm{EC}_{1: 2}\left(\mathrm{dS} \mathrm{m}^{-1}\right)$ at $25^{\circ} \mathrm{C}$ & 0.10 & Conductivity meter (Richards 1954) \\
\hline 6 & Organic Carbon (\%) & 0.51 & Wet oxidation method using $\mathrm{K}_{2} \mathrm{Cr}_{2} \mathrm{O}_{7}$ (Walkley and Black 1934) \\
\hline 7 & Available $\mathrm{N}(\mathrm{Kg} / \mathrm{ha})$ & 206.40 & $\begin{array}{l}\text { Kjeldahl method/ alkaline potassium permanganate oxidation method (Subbiah and Asija } \\
\text { 1956) }\end{array}$ \\
\hline 8 & Available P (Kg/ha) & 8.17 & Olsen's sodium bicarbonate method (Olsen et al. 1954) \\
\hline 9 & Available K (Kg/ha) & 177.80 & Neutral normal ammonium acetate method (Stanford and, English 1949) \\
\hline 10 & $\mathrm{~S}(\mathrm{Kg} / \mathrm{ha})$ & 32.63 & Calcium chloride extraction method (William and Steinbergs 1962) \\
\hline 11 & Zn (ppm) & 1.07 & DTPA extraction method (Lindsay and Norvell 1978) \\
\hline 12 & $\mathrm{Cu}(\mathrm{ppm})$ & 3.41 & DTPA extraction method (Lindsay and Norvell 1978) \\
\hline 13 & $\mathrm{Fe}(\mathrm{ppm})$ & 9.01 & DTPA extraction method (Lindsay and Norvell 1978) \\
\hline 14 & Mn (ppm) & 9.27 & DTPA extraction method (Lindsay and Norvell 1978) \\
\hline 15 & Bulk density & 1.33 & Core method (Blake 1965) \\
\hline 16 & $\operatorname{CEC}\left(\mathrm{cmol}\left(\mathrm{p}^{+}\right) \mathrm{kg}^{-1}\right)$ & 17.34 & Ammonium acetate method (Chapman 1965) \\
\hline 17 & Texture & $\begin{array}{l}\text { Silty clay } \\
\text { loam }\end{array}$ & Texture triangle hydrometer method (Bouyoucos 1962) \\
\hline 18 & Order & Entisol & Soil taxonomy classification method (USDA 1999) \\
\hline
\end{tabular}

Acetamiprid 20\% SP formulation (under Trade name SPARK manufactured by Hindustan Agro Chemicals) was applied in the paddy field in two doses: single dose [SD i.e. $20 \mathrm{~g}$ active ingredient (a.i.) ha ${ }^{-1}$ ] and double dose (DD i.e. $40 \mathrm{~g}$ a.i. ha ${ }^{-1}$ ) along with untreated control throughout the experiment. Similarly, Buprofezin $25 \%$ SC (under Trade name BANZO manufactured by Biostadt India Limited) was sprayed over the rice field in dosages of $200 \mathrm{~g}$ a.i. ha ${ }^{-1}$ as single 
dose (SD) and $400 \mathrm{~g}$ a.i. $\mathrm{ha}^{-1}$ as double dose (DD) in addition to untreated control. Each experiment was conducted in $20 \mathrm{~m}^{2}$ plots in triplicates. These two insecticides were applied thrice since the start of tillering to panicle initiation stage at an interval of 3,7 and 15 days. The residues of the pesticide formulation were investigated in paddy (grain and straw) and soil.

\section{Sampling}

To investigate the dissipation of pesticide formulation (acetamiprid 20\% SP and buprofezin 25\% SC) in paddy (grain and straw) and soil, pesticide formulations were sprayed once in the tillering stage of rice. In order to achieve valid detection of residues even at 10-15 days after spraying, the treatment dosages for the dissipation study were set as $20 \mathrm{~g}$ a.i. ha ${ }^{-1}$ and $40 \mathrm{~g}$ a.i. ha ${ }^{-1}$ for acetamiprid, and $200 \mathrm{~g}$ a.i. ha ${ }^{-1} \mathrm{and}_{400 \mathrm{~g} \text { a.i. ha }}{ }^{-1}$ for buprofezin. Sufficient quantities of paddy grain, straw and soil (about $500 \mathrm{~g}$ each) samples were collected from 10-12 randomly chosen sampling points in each plot at 0 (2 hours after spraying), 1, 3, 5, 7, 10 and 15 days after spraying following a modified sampling plan (Oulkar et al. 2009). The soil was randomly sampled to a depth of $0-15 \mathrm{~cm}$ in each plot using a soil-sampling apparatus. All samples were stored in a deep freezer $\left(-20^{\circ} \mathrm{C}\right)$ until analysis.

\section{Sample preparation and analysis}

The soil samples were made free from stones and weeds, pulverized thoroughly and passed through 2 mm sieve to get fine powder. Rice straw samples were chopped to small pieces, and grains were detached by a threshing machine followed by grinding by a vegetation disintegrator to make coarse powder.

The samples of soil $(10 \mathrm{~g})$, grain $(5 \mathrm{~g})$ and straw $(2 \mathrm{~g})$ were kept separately into a centrifuge tube (50 ml capacity), followed by addition of ultrapure water (5 $\mathrm{ml}$ ) and acetonitrile (10 $\mathrm{ml}$ for the paddy samples and $20 \mathrm{ml}$ for the soil samples). The tubes were continuously shaken for $30 \mathrm{minutes}$ by an oscillator (air bath). Then, $\mathrm{NaCl}(3 \mathrm{~g})$ was added and subjected to oscillation by a vortex mixer for $1 \mathrm{~min}$. The mixture was then centrifuged (5 minutes, $3800 \mathrm{rpm})$, and the supernatant acetonitrile layer $(1 \mathrm{ml})$ was transferred into a centrifuge tube ( $2 \mathrm{ml}$ capacity) containing PSA ( $50 \mathrm{mg}$ ). The centrifuge tube was shaken for 1 minute on a vortexer and then again centrifuged for 3 minutes at $10000 \mathrm{rpm}$. The supernatant was passed through a $0.22 \mu \mathrm{m}$ polypropylene filter and collected into an autosampler vial for HPLC analysis.

\section{HPLC Operating conditions}

Analytical determinations were attained using high performance liquid chromatography (HPLC, Model No. Shimadzu LC-2010CHT) having Perfectsil C18 stainless steel column $(250 \times 4.6 \mathrm{~mm}$ i.d., $5 \mu \mathrm{m}$ particle size) coupled with ultraviolet (UV) detector. The standardized mobile phase was an isocratic elution of solvent mixtures comprising of equal $(1: 1, \mathrm{v} / \mathrm{v})$ quantity of acetonitrile (Sigma-Aldrich, HPLC grade) and water (Sigma-Aldrich, HPLC grade) containing $0.1 \%$ orthophosphoric acid. The injection volume was $20 \mu \mathrm{l}$. The column temperature was maintained at $35^{\circ} \mathrm{C}$ and the flow rate was $0.8 \mathrm{~mL}$ min ${ }^{-1}$ with the run time of 20 minutes. The wavelength ( $\lambda_{\max }$ value) for acetamiprid was $254 \mathrm{~nm}$ with retention times of 4.7 minutes and 10.7 minutes for acetamiprid and buprofezin respectively. The data were processed utilizing system software Empower 2 (version 5.1).

\section{Method validation}

Analytical method validation was performed following standardized guidelines given by the European Commission (SANTE 2017 and EURACHEM 2021).

\section{Calibration curves and linearity}

The calibration curve was prepared by establishing six concentration points with calibration standards in the range of $0.001-0.50 \mu \mathrm{g} \mathrm{ml}{ }^{-1}$ in solvent as well as in the extract of matrix (control). The linearity curve was plotted by the concentrations against the responses (area of the peak) (Figs. 1 and 2).

\section{Selectivity and sensitivity}

Sensitivity was evaluated by the limit of quantification (LOQ) in different matrices (soil, grain and straw)

\section{Recovery study}

Recovery was performed at $0.01,0.02,0.05,0.10,0.50 \mathrm{mg} / \mathrm{kg}$ levels for acetamiprid and at $0.02,0.03,0.05,0.1 \mathrm{and} 0.5 \mathrm{mg} / \mathrm{kg}$ for buprofezin. The matrix effect (ME) was assessed by post-extraction spiking at $0.02,0.03,0.05,0.1$ and 0.5 levels in comparison to solvent standard response.

\section{$M E(\%)=\frac{(\text { Peak area of matrix matched standard }- \text { Peak area of solvent Standard })}{\text { Peak area of matrix matched standard }} \times 100$ \\ Dissipation kinetics and waiting periods}

Dissipation for acetamiprid and buprofezin was studied by plotting the data to the first order kinetic equation:

$A_{t}=A_{0} e^{-k t}$

Where, $A_{t}=$ the concentration at time $t, A_{0}$ the initial concentration, $k=$ the rate constant for dissipation of insecticides, and $t=$ the time.

Calculation of half-life $\left(t_{1 / 2}\right)$ was required to an analysis by the following equation:

$t_{1 / 2}=\ln 2 / k$

The Pre-harvest intervals (PHI) can be calculated in terms of the time (days) required to dissipate of the initial deposition after insecticides sprayings to below the maximum residue limit (MRL). Straw as such cannot be used for direct consumption by human beings, but it can be used for mushroom production, 
conversion to the sugar syrup and yeast protein, which is further consumed by human beings. Hence, determination of PHI for both the products are necessary. Each pesticide has its own PHI, which also varies from crop to crop. In first-order kinetics, it was calculated by the following equation:

$\mathrm{PHI}=[\log ($ intercept $)-\log (\mathrm{MRL})] /$ slope

The residue data, after plotting against time (days) were fitted to TableCurve $2 \mathrm{D}$, where $(1+1)^{\text {st }}$ order kinetics were followed during calculation in the $2 \mathrm{D}$ curve. According to FSSAl, the MRL values of $0.01 \mathrm{mg} \mathrm{kg}^{-1}$ and $0.05 \mathrm{mg} \mathrm{kg}^{-1}$ for acetamiprid and buprofezin respectively are considered.

\section{Consumer food safety assessment}

The food safety of acetamiprid and buprofezin in paddy grain was determined as per the reported literature (Majumder et al. 2020). The maximum permissible intake (MPIs) were estimated by multiplying the acceptable daily intake (ADI) by the average body weight of child (approx. $16 \mathrm{~kg}$ ). The ADI of acetamiprid and buprofezin was 0.025 and $0.01 \mathrm{mg} \mathrm{kg}^{-1}$ body weight day respectively (EU 2020). Dietary exposures were calculated by multiplying the acetamiprid and buprofezin residue present in each sample $\left(\mathrm{mg} \mathrm{kg}^{-1}\right.$ ) with consumption (per person) of $0.270 \mathrm{~kg} \mathrm{day}^{-1}$ of cereals (rice) (ICMR-NIN 2020).

\section{Results And Discussion}

\section{Method validation}

To satisfy the specification of MRLs for acetamiprid and buprofezin residue in paddy grain by the Food Safety and Standard Authority of India (FSSAI), the method was validated as stated in the SANTE guideline (SANTE 2017) validation system. The percentage recovery was determined at five levels in all the

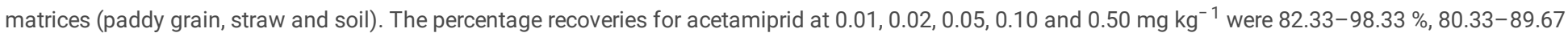
$\%$ and $79.67-81.67 \%$ in grain, straw and soil respectively. In case of buprofezin, percentage recovery data at $0.02,0.03,0.05,0.10$ and $0.50 \mathrm{mg} \mathrm{kg}{ }^{-1}$ were varying from 80.00 to $93.67 \%$ (Table 2). The coefficient of determination $\left(R^{2}\right)$ were more than 0.987 for both the pesticides within the calibration range of $0.02-0.5 \mathrm{mg} / \mathrm{kg}$ for solvent standards as well as matrix standards. The average matrix effect (ME) percentage of acetamiprid and buprofezin were less than $5.00 \%$ for paddy grain, 6.00 to $7.20 \%$ for straw and 5.70 to $7.40 \%$ for soil. The LOQ of acetamiprid was $0.01 \mathrm{mg} \mathrm{kg}^{-1} \mathrm{and} \mathrm{for} \mathrm{buprofezin} 0.02 \mathrm{mg} \mathrm{kg}^{-1}$ in paddy grain, straw and soil sample. The method optimized data in the present research satisfied the SANTE 2017 guidelines for the determination of acetamiprid and buprofezin residue in the matrices of paddy grain, straw and soil.

Table 2

Percent recovery of acetamiprid and buprofezin from paddy grain, straw and soil

\begin{tabular}{|c|c|c|c|c|c|c|}
\hline \multirow[t]{2}{*}{ Sample Types } & \multicolumn{3}{|l|}{ Acetamiprid } & \multicolumn{3}{|l|}{ Buprofezin } \\
\hline & Fortification level $\left(\mathrm{mg} \mathrm{kg}^{-1}\right)$ & Recovery (\%) & $\%$ RSD & Fortification level $\left(\mathrm{mg} \mathrm{kg}^{-1}\right)$ & Recovery (\%) & $\%$ RSD \\
\hline \multirow[t]{5}{*}{ Paddy grain } & 0.01 & 82.33 & 1.86 & 0.02 & 81.33 & 3.09 \\
\hline & 0.02 & 85.67 & 1.35 & 0.03 & 82.33 & 0.70 \\
\hline & 0.05 & 90.33 & 1.28 & 0.05 & 86.67 & 2.40 \\
\hline & 0.10 & 93.33 & 1.64 & 0.1 & 91.33 & 1.67 \\
\hline & 0.50 & 98.33 & 1.17 & 0.5 & 93.67 & 2.22 \\
\hline \multirow[t]{5}{*}{ Paddy straw } & 0.01 & 84.67 & 0.68 & 0.02 & 82.33 & 0.70 \\
\hline & 0.02 & 80.33 & 1.90 & 0.03 & 81.33 & 1.88 \\
\hline & 0.05 & 82.00 & 2.11 & 0.05 & 84.33 & 1.37 \\
\hline & 0.10 & 86.33 & 0.67 & 0.1 & 89.00 & 1.12 \\
\hline & 0.50 & 89.67 & 1.70 & 0.5 & 91.67 & 0.63 \\
\hline \multirow[t]{5}{*}{ Soil } & 0.01 & 81.67 & 1.41 & 0.02 & 81.33 & 1.88 \\
\hline & 0.02 & 81.00 & 1.23 & 0.03 & 80.00 & 1.25 \\
\hline & 0.05 & 81.67 & 2.83 & 0.05 & 83.67 & 1.83 \\
\hline & 0.10 & 79.67 & 1.92 & 0.1 & 87.33 & 1.75 \\
\hline & 0.50 & 81.33 & 1.88 & 0.5 & 90.33 & 0.64 \\
\hline
\end{tabular}

\section{Residues of acetamiprid and buprofezin}

After the final spray, the initially deposited residues of acetamiprid were found to be 0.36 and $0.75 \mathrm{mg} \mathrm{kg}^{-1}$ in paddy grain, 0.31 and $0.71 \mathrm{mg} \mathrm{kg}-1$ in paddy straw and 0.29 and $0.63 \mathrm{mg} \mathrm{kg}^{-1}$ in soil for single and double doses respectively (Table 3). Acetamiprid was degraded at a faster rate up to 5 days after application (DAA) in paddy grain and straw, whereas in case of soil, it was very slow, viz. initially degraded at a slower rate (up to 5 DAA), and however, all residues reached below detectable limit (BDL) in all the matrices on 15 DAA. 
Table 3

Acetamiprid residue persistence in paddy grain, straw and soil

\begin{tabular}{|c|c|c|c|c|c|c|c|c|c|c|c|c|}
\hline \multicolumn{5}{|c|}{ Persistence of acetamiprid in paddy grain } & \multicolumn{4}{|c|}{ Persistence of acetamiprid in paddy straw } & \multicolumn{4}{|c|}{ Persistence of Acetamiprid in Soil } \\
\hline \multirow{2}{*}{$\begin{array}{l}\text { Days } \\
\text { Interval }\end{array}$} & \multicolumn{2}{|c|}{ Single dose (SD) } & \multicolumn{2}{|c|}{ Double dose (DD) } & \multicolumn{2}{|c|}{ Single dose (SD) } & \multicolumn{2}{|c|}{ Double dose (DD) } & \multicolumn{2}{|c|}{ Single dose (SD) } & \multicolumn{2}{|c|}{ Double dose ( [} \\
\hline & $\begin{array}{l}\text { Residue } \\
\text { (mg } \\
\left.\mathrm{kg}^{-1}\right)\end{array}$ & $\begin{array}{l}\text { Dissipation } \\
\text { (\%) }\end{array}$ & $\begin{array}{l}\text { Residue } \\
\text { (mg } \\
\left.\mathrm{kg}^{-1}\right)\end{array}$ & $\begin{array}{l}\text { Dissipation } \\
(\%)\end{array}$ & $\begin{array}{l}\text { Residue } \\
\text { (mg } \\
\left.\mathrm{kg}^{-1}\right)\end{array}$ & $\begin{array}{l}\text { Dissipation } \\
(\%)\end{array}$ & $\begin{array}{l}\text { Residue } \\
\text { (mg } \\
\left.\mathrm{kg}^{-1}\right)\end{array}$ & $\begin{array}{l}\text { Dissipation } \\
\text { (\%) }\end{array}$ & $\begin{array}{l}\text { Residue } \\
\text { (mg } \\
\left.\mathrm{kg}^{-1}\right)\end{array}$ & $\begin{array}{l}\text { Dissipation } \\
(\%)\end{array}$ & $\begin{array}{l}\text { Residue } \\
\text { (mg } \\
\left.\mathrm{kg}^{-1}\right)\end{array}$ & $\begin{array}{l}\text { Dis: } \\
(\%)\end{array}$ \\
\hline 0 & 0.36 & - & 0.75 & - & 0.31 & - & 0.71 & - & 0.29 & - & 0.63 & - \\
\hline 1 & 0.2 & 44.44 & 0.43 & 42.67 & 0.23 & 25.81 & 0.55 & 22.54 & 0.26 & 10.34 & 0.54 & 9.5: \\
\hline 3 & 0.11 & 69.44 & 0.27 & 64.00 & 0.12 & 61.29 & 0.28 & 60.56 & 0.19 & 34.48 & 0.45 & 23.1 \\
\hline 5 & 0.05 & 86.11 & 0.17 & 77.33 & 0.07 & 77.42 & 0.18 & 74.65 & 0.11 & 62.07 & 0.31 & 42.1 \\
\hline 7 & 0.04 & 88.89 & 0.09 & 88.00 & 0.06 & 80.65 & 0.1 & 85.92 & 0.06 & 79.31 & 0.2 & 68.: \\
\hline 10 & 0.02 & 94.44 & 0.05 & 93.33 & 0.01 & 96.77 & 0.07 & 90.14 & 0.03 & 89.66 & 0.09 & $85^{\circ}$ \\
\hline 15 & BDL & - & 0.04 & 94.67 & BDL & - & 0.05 & 92.96 & BDL & - & 0.03 & 95.: \\
\hline
\end{tabular}

In case of buprofezin, initially deposited residues were found to be 0.27 and $0.63 \mathrm{mg} \mathrm{kg}^{-1}$ in paddy grain, 0.23 and $0.61 \mathrm{mg} \mathrm{kg}{ }^{-1}$ in paddy straw and 0.24 and $0.47 \mathrm{mg} \mathrm{kg}^{-1}$ in soil for single and double doses respectively (Table 4). Initially, buprofezin was degraded slowly in all the matrices. Growth dilution between the application of pesticides and sampling may be held prime responsible for dissipation and degradation of pesticide residues. Secondary causes possibly include volatilization occurring during the initial periods after application, decomposition by sunlight and heat, UV radiation, removal by weathering, or other complex conditions (Li et al. 2006).

Table 4

Buprofezin residue persistence in paddy grain, straw and soil

\begin{tabular}{|c|c|c|c|c|c|c|c|c|c|c|c|c|}
\hline \multicolumn{5}{|c|}{ Persistence of buprofezin in paddy grain } & \multicolumn{4}{|c|}{ Persistence of buprofezin in paddy straw } & \multicolumn{4}{|c|}{ Persistence of buprofezin in Soil } \\
\hline \multirow{2}{*}{$\begin{array}{l}\text { Days } \\
\text { Interval }\end{array}$} & \multicolumn{2}{|c|}{ Single dose (SD) } & \multicolumn{2}{|c|}{ Double dose (DD) } & \multicolumn{2}{|c|}{ Single dose (SD) } & \multicolumn{2}{|c|}{ Double dose (DD) } & \multicolumn{2}{|c|}{ Single dose (SD) } & \multicolumn{2}{|c|}{ Double dose ( [} \\
\hline & $\begin{array}{l}\text { Residue } \\
\text { (mg } \\
\left.\mathrm{kg}^{-1}\right)\end{array}$ & $\begin{array}{l}\text { Dissipation } \\
\text { (\%) }\end{array}$ & $\begin{array}{l}\text { Residue } \\
\text { (mg } \\
\left.\mathrm{kg}^{-1}\right)\end{array}$ & $\begin{array}{l}\text { Dissipation } \\
\text { (\%) }\end{array}$ & $\begin{array}{l}\text { Residue } \\
\text { (mg } \\
\left.\mathrm{kg}^{-1}\right)\end{array}$ & $\begin{array}{l}\text { Dissipation } \\
(\%)\end{array}$ & $\begin{array}{l}\text { Residue } \\
\text { (mg } \\
\left.\mathrm{kg}^{-1}\right)\end{array}$ & $\begin{array}{l}\text { Dissipation } \\
(\%)\end{array}$ & $\begin{array}{l}\text { Residue } \\
\text { (mg } \\
\left.\mathrm{kg}^{-1}\right)\end{array}$ & $\begin{array}{l}\text { Dissipation } \\
(\%)\end{array}$ & $\begin{array}{l}\text { Residue } \\
\text { (mg } \\
\left.\mathrm{kg}^{-1}\right)\end{array}$ & $\begin{array}{l}\text { Dis: } \\
(\%)\end{array}$ \\
\hline 0 & 0.27 & - & 0.63 & - & 0.23 & - & 0.61 & - & 0.24 & - & 0.47 & - \\
\hline 1 & 0.23 & 34.29 & 0.56 & 16.00 & 0.21 & 27.59 & 0.57 & 19.72 & 0.23 & 32.35 & 0.35 & 47. \\
\hline 3 & 0.22 & 37.14 & 0.48 & 24.00 & 0.18 & 37.93 & 0.51 & 28.17 & 0.19 & 44.12 & 0.32 & $52 .:$ \\
\hline 5 & 0.19 & 45.71 & 0.41 & 31.00 & 0.11 & 62.07 & 0.39 & 45.07 & 0.12 & 64.71 & 0.19 & 71.1 \\
\hline 7 & 0.09 & 74.29 & 0.28 & 44.00 & 0.07 & 75.86 & 0.26 & 63.38 & 0.07 & 79.41 & 0.17 & 74.1 \\
\hline 10 & 0.05 & 85.71 & 0.12 & 60.00 & 0.05 & 82.76 & 0.14 & 80.28 & 0.04 & 88.24 & 0.14 & 79. \\
\hline 15 & 0.04 & 88.57 & 0.04 & 68.00 & BDL & - & 0.07 & 90.14 & $\mathrm{BDL}$ & - & 0.03 & 95.! \\
\hline
\end{tabular}

\section{Dissipation kinetics and waiting periods}

The dissipation behaviour of acetamiprid in paddy and soil are different. It was initially faster in paddy, however, in soil it was slowed down over time. This indicated an exponential degradation pattern following simple first-order kinetics that is sufficient to explain the dissipation dynamics of the insecticide residues. The similar pattern was observed for buprofezin with the $\mathrm{R}^{2}$ value of more than 0.90 for both the pesticides in all the matrices (Figs. 3, 4, 5, 6, 7 and 8). Considering at the dataset of different sampling days (Tables 3 and 4), the PHIs estimated through first order kinetics were adequate in minimizing the residue level (i.e., < MRL), implying the appropriateness of this model to define the dissipation kinetics of acetamiprid and buprofezin residues in all the matrices. The PHIs for acetamiprid in grain and straw were 11.67 days and 11.82 days respectively for SD. Whereas PHI for buprofezin (SD) in case of paddy grain was 12.42 days and in case of straw was 9.69 days. One interesting point to note that the PHIs of both the pesticides at DD for straw matrices were beyond 15 days which signified that there would be much time needed to degrade the active ingredient and harvesting should be delayed after 15 days. In case of paddy grain matrix, buprofezin showed 13.93 days that was nearer to 15 days, which revealed that paddy grain was ready to harvest shortly, whereas straw required more time to be ready for further use after application of buprofezin pesticide.

In this kinetics model of acetamiprid for paddy matrix, one fraction of the applied pesticide went right away to the solution phase, where they degraded rapidly and the remaining portion possibly settled in a dynamic equilibrium while being adsorbed on cellular components. This happened owing to the rapid degradation of the insecticide residues in paddy at the double dose. As buprofezin has contact activity, so the presence of free (unabsorbed) molecules on paddy surfaces (exposed to the sunlight and other environmental factors resulting in degradation) might be higher for double dose that led to a comparably quicker rate of degradation. Almost $40 \%$ of the initial deposits of acetamiprid dissipated within 24 hours (day 1 ) of application for both doses, with more than $95 \%$ dissipation found by day 10 in case of paddy grain matrices, whereas in case of paddy straw almost $20 \%$ dissipated within day 1 and almost $90 \%$ dissipated by day 10 for both single and double dose. For the soil, the acetamiprid dissipation was around $10 \%$ within day 1 and came to almost $86 \%$ by day 
10 for both the doses that indicated its slower degradation in the soil matrix. In the case of buprofezin, there was no similar behaviour observed for single and double dose in case of paddy grain matrix. It dissipated $89 \%$ at 15 days for single dose, whereas $68 \%$ for double dose. In the other two matrices, it followed the same pattern like acetamiprid. For paddy straw, it dissipated around $80 \%$ by 10 days for both the doses, whereas in case of soil, more than $80 \%$ degraded by 10 days. It suggested that acetamiprid had a higher rate of degradation compared to buprofezin. The probable reason can be the functional group attached to the moieties present in both the compounds. Acetamiprid, due to the attachment of chlorine (Cl) as an electronegative group at pyridine moiety, was susceptible to release labile group as chloro-pyridine resulting in a faster dissipation compared to buprofezin, where no electronegative group was attached to pyrimidine moiety. The half-lives of acetamiprid in case of single dose for paddy grain, straw and soil were $2.47,2.19$ and 2.95 days respectively, whereas, in case of double dose for the same matrices were 1.37, 1.48 and 1.43 days respectively. The half-lives of buprofezin in case of single dose for paddy grain, straw and soil were 4.88, 4.23 and 3.67 days respectively, whereas, in case of double dose for the same matrices were $3.75,4.56$ and 4.17 days respectively. Previous experiments reported half-lives of acetamiprid in the range of 1-2 days for plant matrices like rice (Saha et al. 2017), okra (Singh and Kulshrestha 2005), mustard (Pramanik et al. 2006) and tea (Gupta and Shanker 2008); however, comparatively higher half-lives (2-5 days) were reported in some literature for watermelon (Wu et al. 2012), cowpea (Fu et al. 2020) and chilli (Sanyal et al. 2008). For soil matrices, half-lives ranging from 5-10 days were generally found (Yu et al. 2011) and in some cases, half-lives of more than 10 days were also observed (Fu et al. 2020; Wu et al. 2012). For buprofezin, the studies on plants and soil were limited and its persistence behaviour was found varying with various crops (Mohapatra et al. 2020). In a study, the half-lives of buprofezin in cabbage were estimated as 1.73 and 1.85 days for SD and DD respectively; and for cauliflower, these values were 2.1 and 2.36 days for SD and DD respectively (Abdallah et al. 2019). In our case, the half-lives were slightly lower than those earlier reports. These might be due to the differences in environmental matrices, agro-climatic conditions, application techniques and other associated factors.

Therefore, the present research evaluated the dynamics of acetamiprid and buprofezin residues in paddy and soil in a holistic way. The PHI data can be useful to paddy growing farmers of a particular location to ascertain the safe use of pesticides for management of rice insect pests, while the half-life values in the soil will help manage the residues of these insecticides in plant, soil and other matrices.

\section{Food safety}

The residues of acetamiprid and buprofezin were dissipated to below MRL with the almost same pattern in rice grain. There is hardly any reported data regarding the safety of acetamiprid and buprofezin in rice and therefore, the safety evaluation associated with these insecticides residues was very crucial. The MPI of acetamiprid and buprofezin was estimated as 0.4 and $0.16 \mathrm{mg}_{\text {person }}{ }^{-1}$ day $^{-1}$ respectively. The dietary exposures of the residues were less than the MPI on all the sampling days for both the doses (Table 5). Therefore, acetamiprid and buprofezin are concluded to possess low toxicity risk when practiced for pest management in paddy.

Table 5

Safety evaluation of day wise residues of acetamiprid and buprofezin in paddy grain

\begin{tabular}{|c|c|c|c|c|c|c|c|c|}
\hline \multirow{3}{*}{$\begin{array}{l}\text { Sampling } \\
\text { days }\end{array}$} & \multicolumn{4}{|c|}{ Acetamiprid } & \multicolumn{4}{|c|}{ Buprofezin } \\
\hline & \multicolumn{2}{|c|}{ Recommended dose } & \multicolumn{2}{|c|}{ Double dose } & \multicolumn{2}{|c|}{ Recommended dose } & \multicolumn{2}{|c|}{ Double dose } \\
\hline & $\begin{array}{l}\text { Residues } \\
\text { (mg kg- } \\
\left.{ }^{1}\right)\end{array}$ & $\begin{array}{l}\text { Dietary exposure } \\
\text { (mg person }{ }^{-1} \text { day }^{-} \\
\text {1) }\end{array}$ & $\begin{array}{l}\text { Residues } \\
\text { (mg kg- } \\
\text { 1) }\end{array}$ & $\begin{array}{l}\text { Dietary exposure } \\
\text { (mg person }{ }^{-1} \text { day }^{-} \\
{ }^{1} \text { ) }\end{array}$ & $\begin{array}{l}\text { Residues } \\
\text { (mg kg- } \\
\left.{ }^{1}\right)\end{array}$ & $\begin{array}{l}\text { Dietary exposure } \\
\text { (mg person }{ }^{-1} \text { day }^{-} \\
\left.{ }^{1}\right)\end{array}$ & $\begin{array}{l}\text { Residues } \\
\text { (mg kg- } \\
\left.{ }^{1}\right)\end{array}$ & $\begin{array}{l}\text { Dietary exposure } \\
\text { (mg person }{ }^{-1} \text { day } \\
\text { 1) }\end{array}$ \\
\hline 0 & 0.36 & 0.097 & 0.75 & 0.203 & 0.27 & 0.073 & 0.63 & 0.170 \\
\hline 1 & 0.2 & 0.054 & 0.43 & 0.116 & 0.23 & 0.062 & 0.56 & 0.151 \\
\hline 3 & 0.11 & 0.030 & 0.27 & 0.073 & 0.22 & 0.059 & 0.48 & 0.130 \\
\hline 5 & 0.05 & 0.014 & 0.17 & 0.046 & 0.19 & 0.051 & 0.41 & 0.111 \\
\hline 7 & 0.04 & 0.011 & 0.09 & 0.024 & 0.09 & 0.024 & 0.28 & 0.076 \\
\hline 10 & 0.02 & 0.005 & 0.05 & 0.014 & 0.05 & 0.014 & 0.12 & 0.032 \\
\hline 15 & $\mathrm{BDL}$ & - & 0.04 & 0.011 & 0.04 & 0.011 & 0.04 & 0.011 \\
\hline
\end{tabular}

\section{Conclusions}

We investigated the residues and dissipation patterns of two insecticides (acetamiprid and buprofezin) under the open-field system for paddy cultivation. An easy and simple analytical method was developed, standardized and validated using liquid chromatographic technique (HPLC) for estimation of residue in soil and paddy matrices. The LOQ values were found to be 0.01 and $0.02 \mathrm{mg} \mathrm{kg}^{-1}$ for acetamiprid and buprofezin respectively in all of the matrices. The study indicated that both insecticides dissipated rapidly with an almost similar pattern in all the three matrices under field condition with acetamiprid having higher dissipation than buprofezin. The PHIs (days) of insecticides were also proposed afore harvest based upon the dissipation equations. Both the insecticides were deemed to maintain a safe toxicological profile in case of dietary exposures of the residues at both doses. It is highly anticipated that this research findings certainly furnish reliable data for apprehending the fate of buprofezin and acetamiprid residues and supply fruitful guidance towards successful residue management and robust assurance to safety of foods. From this study, a package of practices can be recommended regarding the application schedule of acetamiprid and buprofezin, with dose, number of sprays, inter-spray interval etc. Thus, this work is of high practical significance to the domestic and export purposes to ensure safety compliance in respect of residues, keeping in view of the requirements of international trade. 


\section{Abbreviations}

\begin{tabular}{ll} 
a.i. & Active ingredient \\
\hline ADI & Acceptable daily intake \\
\hline BDL & Below detectable limit \\
\hline CIB & Central Insecticide Board \\
\hline CRM & Certified Reference Material \\
\hline DD & Double dose \\
\hline FSSAI & Food Safety and Standard Authority of India \\
\hline GC-MS & Gas Chromatography - Mass Spectrometry \\
\hline HPLC & High Performance Liquid Chromatography \\
\hline LC-MS & Liquid Chromatography - Mass Spectrometry \\
\hline LOD & Limit of detection \\
\hline LOQ & Limit of quantification \\
\hline ME & Matrix effect \\
\hline MPI & Maximum permissible intake \\
\hline MRL & Maximum residue limit \\
\hline nAChR & Nicotinic acetylcholine receptor \\
\hline PHI & Pre-harvest interval \\
\hline PSA & Primary secondary amine \\
\hline RBD & Randomized Block Design \\
\hline RC & Registration Committee \\
\hline SD & Single dose \\
\hline
\end{tabular}

\section{Declarations}

\section{Ethics approval and consent to participate}

Not applicable.

\section{Consent for publication}

Not applicable.

\section{Availability of data and materials}

Data sharing is not applicable to this article as no datasets were generated or analyzed during the current study.

\section{Competing interests}

The authors declare that they have no competing interests.

\section{Funding}

The authors are thankful to Krishi Rasayan Pvt. Ltd. for financial assistance.

\section{Authors' contributions}

This work was carried out in collaboration among all authors. $\mathrm{PM}, \mathrm{S}_{0} \mathrm{M}$ and $\mathrm{S}_{\mathrm{U}} \mathrm{M}$ designed the study and wrote the protocol. $\mathrm{BM}, \mathrm{S}_{0} \mathrm{M}$ and $\mathrm{S}_{U} \mathrm{M}$ managed the analysis of the study. AP, TP and NS made data interpretation. $S_{U} M$ and PM were major contributors in writing the manuscript. All authors thoroughly read and approved the final manuscript.

\section{Acknowledgements}

This research is a subsidiary study from an original project work entitled as "Residue analysis of Buprofezin $20 \%+$ Acetamiprid $2 \%$ WP on rice" (Ref. No. UBKV/DR-63; project code: 18.28) supported by Krishi Rasayan Exports Pvt. Ltd., India. The instrumental facilities furnished by the Central Instrumentation Centre (CIC) and Quality Control Laboratory (QCL), UBKV is duly acknowledged. The authors are thankful to Dr. Ashok Choudhury (Director of Research) and 
Professor Ashutosh Sarkar (In-Charge, Regional Research Station, Terai Zone) from Uttar Banga Krishi Viswavidyalaya, Cooch Behar, West Bengal, India for constant motivation and support.

\section{References}

1. Abdallah O, El Agamy M, Abdelraheem E, Malhat F (2019) Buprofezin dissipation and safety assessment in open field cabbage and cauliflower using GC/ITMS employing an analyte protectant. Biomed Chromatogr 33:e4492

2. Ane N-UI, Hussain M (2016) Diversity of insect pests in major rice growing areas of the world. J Entomol Zool Stud 4(1):36-41

3. Bajaj S, Mohanty A (2005) Recent advances in rice biotechnology towards genetically superior transgenic rice. Plant Biotechnol J 3:275-307

4. Blake GR (1965) Bulk density, in: C.A. Black (Ed.), Methods of Soil Analysis, Part 1: Physical and Mineralogical Properties, including Statistics of Measurement and Sampling Method of Soil Analysis, Agron, vol. 9, pp. 374-390

5. Bouyoucos GJ (1962) Hydrometer method improved for making particle size analysis of soils. Agron J 54:464-465

6. Burlando B, Cornara L (2014) Therapeutic properties of rice constituents and derivatives (Oryza sativa L.): A review update. Trends Food Sci Technol 40:82-98

7. Chapman HD (1965) Cation-exchange capacity, in: C.A. Black (Ed.), Methods of Soil Analysis, Part 2: Chemical and Microbiological Properties, Am Soc Agron, vol. 9, pp. 891-901

8. Chen H, Gao G, Chai Y, Ma G, Hao Z, Wang C, Liu X, Lu C (2017) Multiresidue Method for the Rapid Determination of Pesticide Residues in Tea Using Ultra Performance Liquid Chromatography Orbitrap High Resolution Mass Spectrometry and In-Syringe Dispersive Solid Phase Extraction. ACS Omega 2(9):5917-5927

9. De Cock A, Degheele D (1998) Buprofezin: A novel chitin synthesis inhibitor affecting specifically planthoppers, whiteflies and scale insects. In: Ishaaya I, Degheele D (eds) Insecticides with novel modes of action: Mechanism and application. Springer, Berlin, pp 74-91

10. DPPQS (Directorate of Plant Protection, Quarantine \& Storage) (2020) Major Uses of Pesticides. Retrieved from: http://www.ppqs.gov.in/sites/default/files/major_use_of_pesticides_insecticides.pdf

11. EU (European Union) (2020) Pesticides database. Retrieved from: https://ec.europa.eu/food/plant/pesticides/eu-pesticides-database/public/? event=homepage\&language $=\mathrm{EN}$

12. EURACHEM (2021) Eurachem Guides - A Focus for Analytical Chemistry in Europe. Retrieved from: https://www.eurachem.org/index.php/publications/guides\#: :text=Eurachem\%20guides\%20are\%20developed\%20by,charge\%20from\%20the\%20Eurache

13. Fu D, Zhang S, Wang M, Liang X, Xie Y, Zhang Y, Zhang C (2020) Dissipation behavior, residue distribution and dietary risk assessment of cyromazine, acetamiprid and their mixture in cowpea and cowpea field soil. J Sci Food Agric 100:4540-4548

14. Gorse C, Johnston D, Pritchard M (2012) A Dictionary of Construction, Surveying, and Civil Engineering. Oxford Quick Reference. OUP Oxford. p. 960. ISBN 978-0-19-104494-6

15. Gupta M, Shanker A (2008) Persistence of acetamiprid in tea and its transfer from made tea to infusion. Food Chem 111:805-810

16. Gupta S, Gajbhiye VT (2007) Persistence of acetamiprid in soil. Bull Environ Contam Toxicol 78:349-352

17. ICMR-NIN (Indian Council of Medical Research - National Institute of Nutrition) (2020) What India Eats. Retrieved from: https://www.nin.res.in/nutrition2020/what_india_eats.pdf

18. IRRI (International Rice Research institute) (2020) World Rice Statistics - Online Query Facility. Retrieved from: http://ricestat.irri.org:8080/wrsv3/entrypoint.htm

19. Ishaaya I, Barazani A, Kontsedalov S, Horowitz AR (2007) Insecticides with novel modes of action: Mechanism, selectivity and cross-resistance. Entomol Res 37:148-152

20. Jackson ML (1973) Methods of Chemical Analysis, Prentice Hall of India. Pvt.) Ltd, New Delhi

21. Lee YD, Jang SW (2010) Determination of Buprofezin Residues in Rice and Fruits Using HPLC with LC/MS Confirmation. Korean J Environ Agric 29(3):247-256

22. Li J-Z, Wu X, Hu J-Y (2006) Determination of Fungicide Kresoxim-Methyl Residues in Cucumber and Soil by Capillary Gas Chromatography with NitrogenPhosphorus Detection. J Environ Sci Health B 41(4):427-436

23. Lindsay WL, Norvell WA (1978) Development of a DTPA soil test for zinc, iron, manganese, and copper. Soil Sci Soc Amer J 42:421-428

24. Majumder S, Verma CK, Rani V, Rani AT, Pandey KK, Singh J (2020) Residue dynamics and food safety evaluation of fungicide kresoxim-methylin green chilli (Capsicum annum L.). Int J Environ Anal Chem. DOI:10.1080/03067319.2020.1830986

25. Melo MG, Carqueijo A, Freitas A, Barbosa Jorge, Silva AS (2020) Modified QuEChERS Extraction and HPLC-MS/MS for Simultaneous Determination of 155 Pesticide Residues in Rice (Oryza sativa L.). Foods 9:18

26. Mohapatra S, Siddamallaiah L, Matadha NY, Gadigeppa S, Raja DP, Udupi VR (2020) Persistence and dissipation study of azoxystrobin, buprofezin, dinocap and hexaconazole on mango (Mangifera indica L.). Environ Sci Pollut Res 27:32820-32828

27. Obana H, Okihashi M, Akutsu K, Kitagawa Y, Hori S (2002) Determination of acetamiprid, imidacloprid, and nitenpyram residues in vegetables and fruits by high-performance liquid chromatography with diode-array detection. J Agric Food Chem 50(16):4464-4467

28. Olsen SR, Cole CV, Watanabe FS, Dean LA (1954) Estimation of available phosphorus in soils by extraction with sodium bicarbonate. Circ US Dept Agric 939:1-19 
29. Oulkar DP, Banerjee K, Patil SH, Upadhyay AK, Taware PB, Deshmukh MB, Adsule PG (2009) Degradation kinetics and safety evaluation of buprofezin residues in grape (Vitis vinifera L.) and three different soils of India. Pest Manag Sci 65:183-188

30. Pramanik SK, Bhattacharyya J, Dutta S, Dey PK, Bhattacharyya A (2006) Persistence of Acetamiprid in/on Mustard (Brassica juncea L.). Bull Environ Contam Toxicol 76:356-360

31. Richards LA (1954) Diagnosis and improvement of saline alkali soils, USDA Handbook 60

32. Saha S, Mondal R, Mukherjee S, Sarkar M, Kole RK (2017) Persistence of acetamiprid in paddy and soil under West Bengal agro-climatic conditions. Environ Monit Assess 189:150. Retrieved from: https://doi.org/10.1007/s10661-017-5871-0

33. SANTE (2017) Guideline document on analytical quality control and method validation procedures for pesticide residue analysis in food and feed. SANTE document no. SANTE/11813/2017. Retrieved from: https://ec.europa.eu/food/sites/food/files/plant/docs/pesticides_mrl_guidelines_wrkdoc_201912682.pdf

34. Sanyal D, Chakma D, Alam S (2008) Persistence of neonicotinoid insecticides, acetamiprid on chilli (Capsicum annum L). Bull Environ Contam Toxicol 81:365-368

35. Sanyal D, Chakma D, Alam S (2008) Persistence of neonicotinoid insecticides, acetamiprid on chilli (Capsicum annum L). Bull Environ Contam Toxicol 81:365-368

36. Sen S, Chakraborty R, Kalita P (2020) Rice - not just a staple food: A comprehensive review on its phytochemicals and therapeutic potential. Trends Food Sci Technol 97:265-285

37. Singh SB, Kulshrestha G (2005) Residues of thiamethoxam and acetamiprid, two neonicotinoid insecticides in/on okra fruits (Abelmoschus esculentus L.). Bull Environ Contam Toxicol 75:945-951

38. Stanford S, English L (1949) Use of flame photometer in rapid soil tests of K. Can J Agron 41:446-447

39. Subbiah BV, Asijja GL (1956) A rapid procedure for the estimation of nitrogen in soils. Curr Sci 25:259-260

40. Thongphak D, Promdeesan K, Hanlaoedrit C (2012) Diversity and community structure of terrestrial invertebrates in an irrigated rice ecosystem. Int J Environ Rural Dev 3(1):68-71

41. Tomizawa M, Casida JE (2005) Neonicotinoid insecticide toxicology: mechanisms of selectivite action. Annu Rev Pharmacol Toxicol 45:247-268

42. USDA (United States Department of Agriculture) (1999) Soil taxonomy: A Basic System of Soil Classification for Making and Interpreting Soil Surveys. 2nd edition by soil survey staff. Natural Resources Conservation Service. United States Department of Agriculture Handbook Number 436

43. Valverde-Garcia A, Gonzalez-Pradas E, Real AA (1993) Analysis of buprofezin residues in vegetables. Application to the degradation study on eggplant grown in a greenhouse. J Agric Food Chem 41(12):2319-2323

44. Walkley A, Black IA (1934) An examination of the Degtjareff method for determining soil organic matter, and a proposed modification of the chromic acid titration method. Soil Sci 37:29-38

45. Wartono, Suwignyo R, Napoleon A, Suheryanto S (2018) Insecticides Residue in the Centre of Paddy Field in MusiRawas, South Sumatera, Indonesia. E3S Web Conf. Volume 68, Article No. 04014. The 1st Sriwijaya International Conference on Environmental Issues. Retrieved from:

https://doi.org/10.1051/e3sconf/20186804014

46. Williams CH, Steinbergs A (1962) The evaluation of plant-available sulphur in soils. Plant Soil 17(3):279-294

47. WMO (World Meteorological Organization) (2009) WMO Field Intercomparison of Rainfall Intensity Gauges (E. Vuerich, C. Monesi, L.G. Lanza, L. Stagi, E. Lanzinger). Instruments and Observing Methods Report No. 99 (WMO/TD-No. 1504), Geneva. Retrieved from: https://library.wmo.int/doc_num.php? explnum_id=9422

48. Wu J, Wang K, Zhang H (2012) Dissipation and residue of acetamiprid in watermelon and soil in the open field. Bull Environ Contam Toxicol 89:644-648 49. Wu J, Wang K, Zhang H (2012) Dissipation and residue of acetamiprid in watermelon and soil in the open field. Bull Environ Contam Toxicol 89:644-648

50. Yu XY, Mu CL, Gu C, Liu C, Liu XJ (2011) Impact of woodchip biochar amendment on the sorption and dissipation of pesticide acetamiprid in agricultural soils. Chemosphere 85:1284-1289

51. Yu Y, Liu X, He Z, Wang L, Luo M, Peng Y, Zhou Q (2016) Development of a multi-residue method for 58 pesticides in soil using QuEChERS and gas chromatography-tandem mass spectrometry. Anal Methods 8(11):2463-2470

52. Zhan G, Lin MS (2009) 'Modified Blaney-Criddle method - an empirical approach to estimate potential evaporation using air temperature', in AB Fourie \& M Tibbett (eds), Proceedings of the Fourth International Conference on Mine Closure, Australian Centre for Geomechanics, Perth, pp. 461-471. Retrieved from: https://doi.org/10.36487/ACG_repo/908_35

\section{Figures}




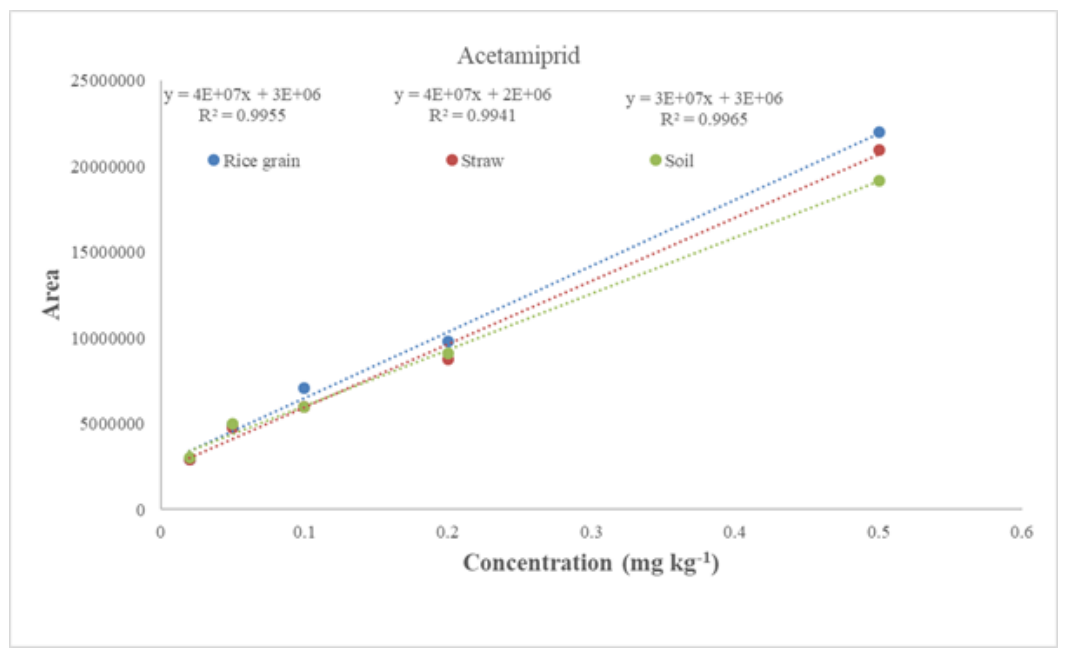

\section{Figure 1}

Linear graph of acetamiprid in different matrices

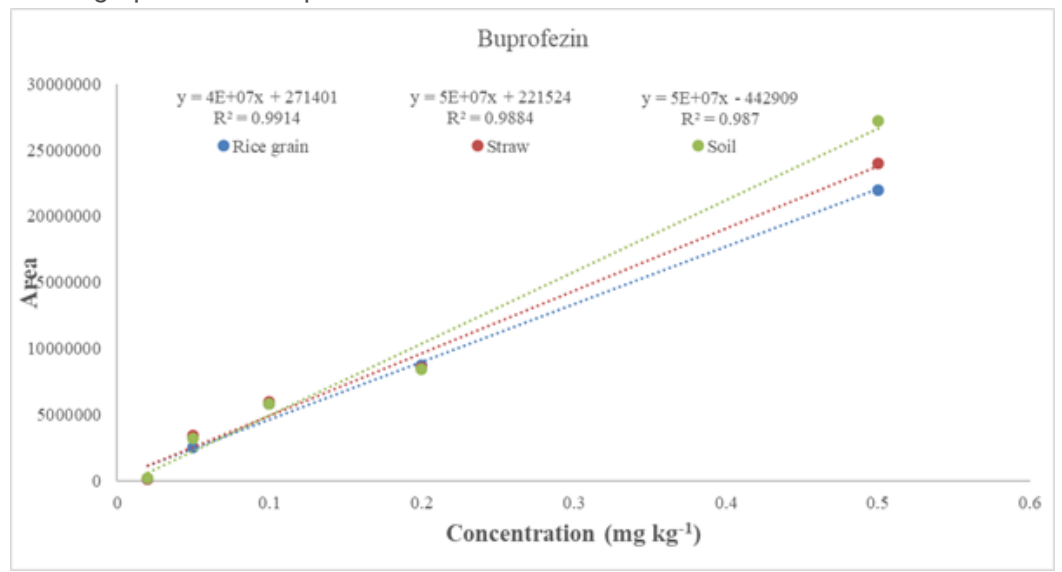

Figure 2

Linear graph of buprofezin in different matrices

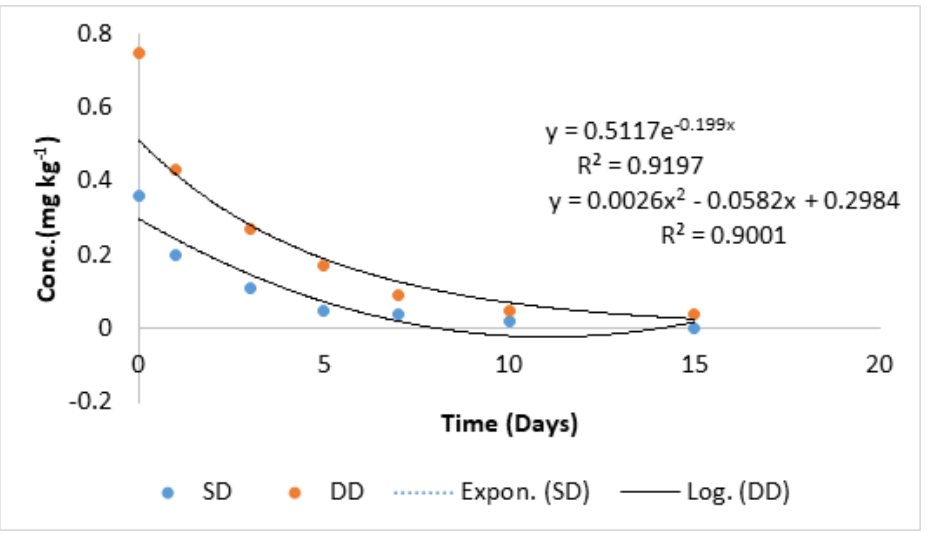

\section{Figure 3}

Acetamiprid dissipation in paddy grain 


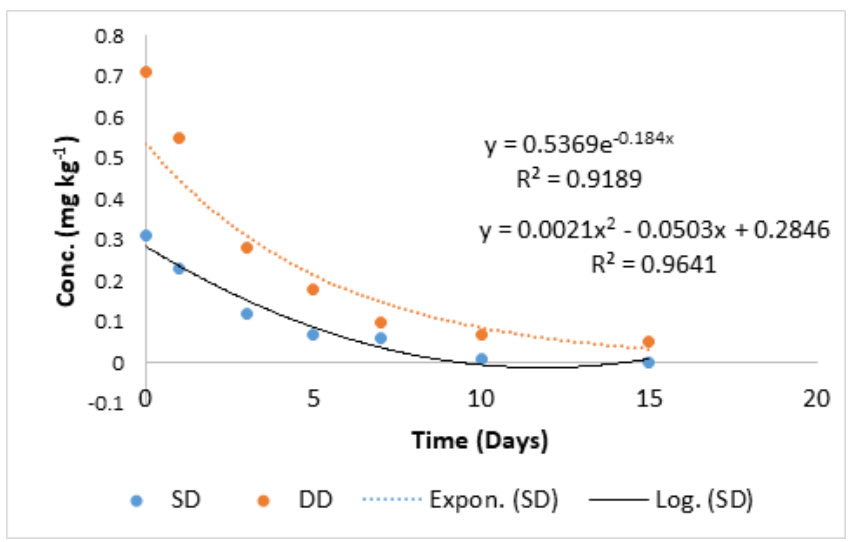

Figure 4

Acetamiprid dissipation in paddy straw

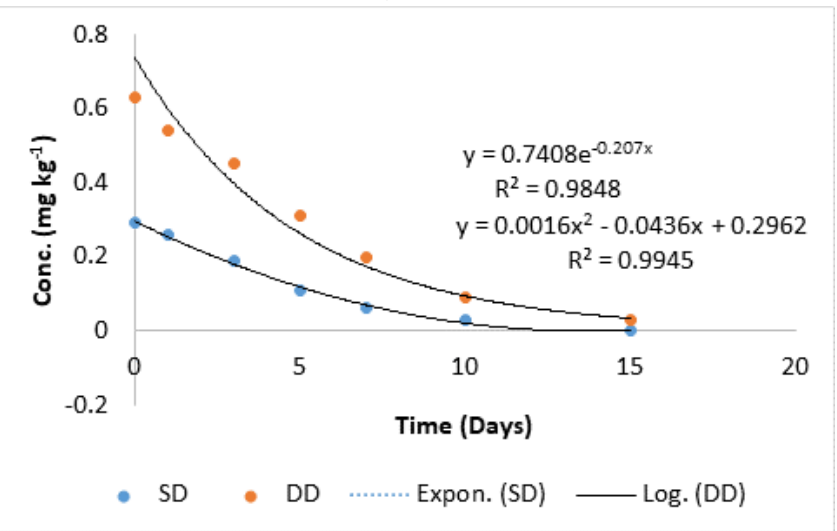

Figure 5

Acetamiprid dissipation in paddy soil

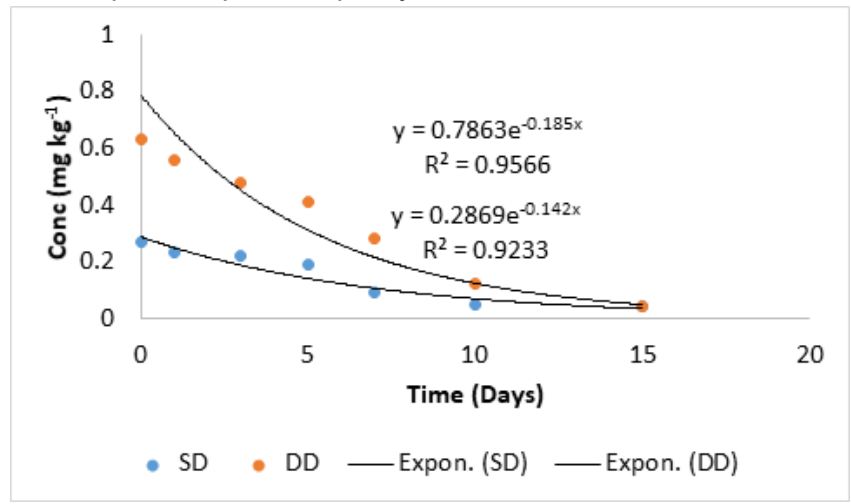

Figure 6

Buprofezin dissipation in paddy grain 


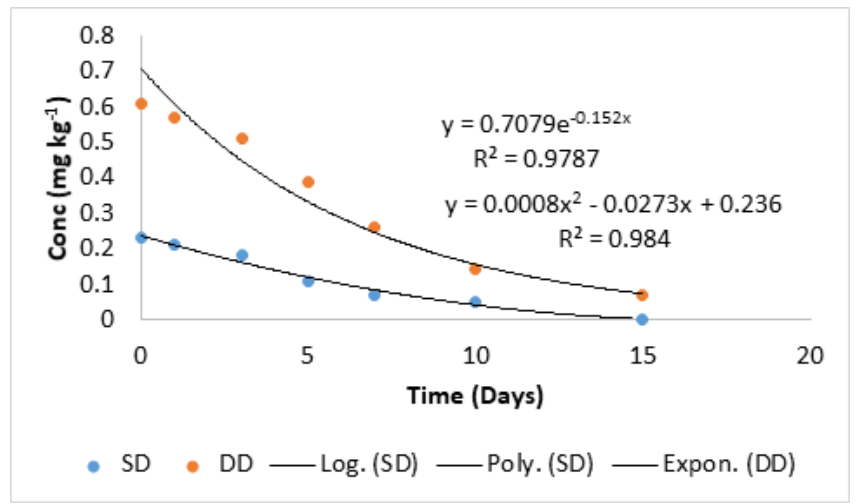

Figure 7

Buprofezin dissipation in paddy straw

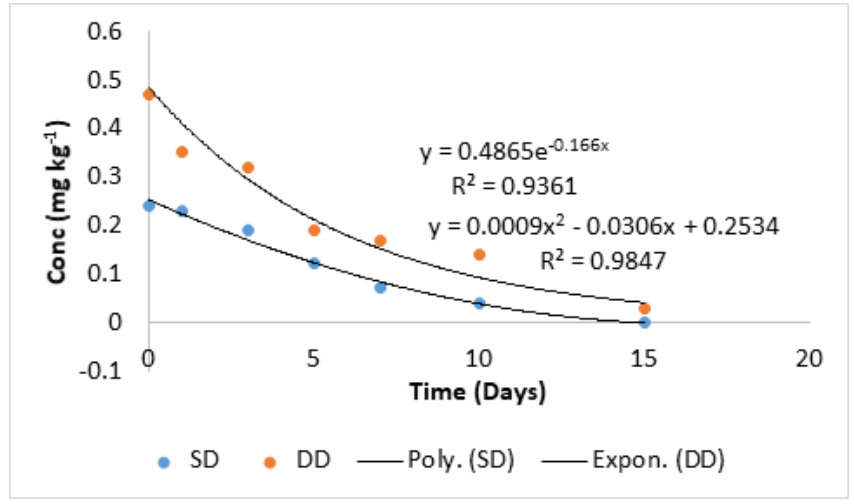

Figure 8

Buprofezin dissipation in paddy soil 